\title{
Cognition application in preschool teaching and learning through communication component in national standard preschool curriculum
}

\author{
Suppiah Nachiappan *, Zaharah Othman, Nur Izaidah Mat Akhir, Nordin Mamat, Mastura Othman
}

Faculty of Education and Human Development, Sultan Idris Education University, Tanjung Malim, Malaysia

\section{A R T I C LE IN F O}

\section{Article history}

Received 22 August 2016

Received in revised form

17 October 2016

Accepted 28 October 2016

\section{Keywords:}

Cognition

Preschool

Hermeneutics method

Communication

Daily teaching plan

\begin{abstract}
A B S T R A C T
This study aims to identify the teacher's shortcomings in teaching preparation, and cognition application in teaching and learning through communication component in National Standard Preschool Curriculum. Teachers' Daily Teaching Plan (DTP) from a teacher for a week in communication component was analyzed using Hermeneutics method. The results obtained showed that there were two main factor of teachers' shortcoming in the DTP which is the repetition of the same activities and the use of uninteresting teaching aids. In addition, the findings also showed that teachers still lacking in implement the cognition application in teaching and learning of communication component. Therefore, the guidance of lecturers and mentors need to address this issue. Teachers also need to attend special training courses to gain knowledge and experiences in order to improve the weaknesses that have been identified.
\end{abstract}

(C) 2016 The Authors. Published by IASE. This is an open access article under the CC BY-NC-ND license (http://creativecommons.org/licenses/by-nc-nd/4.0/)

\section{Introduction}

Literacy and language skills, is vital and necessary to every child. This is because language and literacy is a mean of communication used by humans throughout life. Students from infancy until the age of eight years will experience a period of critical change and development for a child to achieve physical and mental skills that will be used for the rest of their life (Noor Aini, 2014). Ministry of Education (2010) emphasizes the skills which include language skills of listening, speaking, reading and writing through the communication component in the National Preschool Standard Curriculum.

Activities based on communication and language needs to be applied in preschool. Language development of students is assisted by social interaction of their environment. By watching appropriate movies or music, helps develop cognitive level of students in preschool through the process of assimilation (Nachiappan, 2015). Meanwhile, reading is an important component for the development of students' cognitive, as reading affect the process of thought, emotion, imagination and personality of the child (Husin and Isa, 2012).

\footnotetext{
* Corresponding Author.

Email Address: suppia@fppm.upsi.edu.my (S. Nachiappan)

https://doi.org/10.21833/ijaas.2016.11.002

2313-626X/C) 2016 The Authors. Published by IASE

This is an open access article under the CC BY-NC-ND license

(http://creativecommons.org/licenses/by-nc-nd/4.0/)
}

Therefore, preschool teachers need to emphasize on the teaching of language and literacy in preschool. This includes practicum teachers who are under training in preschool. Teaching strategies are important. To ensure that the learning objectives are achieved, a teacher must know how to manage, administer and control the students in the classroom to ensure that the content of the lesson can be understood by all students. Teachers no longer act as a source of knowledge, but as facilitators, change agents and a source of inspiration to students (Razak and Nordin, 2013). To make the teaching and learning effective, interesting and fun, a teacher must be creative, innovative and have a high knowledge.

\section{Literature review}

Language and human thoughts are closely interlinked because the language is not formed in the surface structure alone, where language has multiple meanings of the word or phrase is used. Language should also be accompanied by human thought to speak. This clearly shows the relationship and the influence of language on cognitive processes. According to Goldstein (2011), cognition refers to two functions, first, what the mind and secondly, how the mind processes the mental activities. Therefore, the development of cognition refers to changes in processes and mental skills according to physiological maturity and the experiences of childhood. These changes are closely related to the interaction between genetics and the environment. 
For education, the level of ability of cognition depends on intrinsic and extrinsic motivation of students (Nachiappan, 2015).

In the area of early childhood education, previous studies showed that the approach used by teachers in the classroom greatly influences the development of language and literacy for students. Indirectly, it also influences the cognitive development of preschool students. According to Alvestad and Sheridan (2015), education can become worthless if the teacher does not have awareness of pedagogy in planning structured or unstructured learning. Teaching in the classroom is very influenced by their pedagogical practices. Chen and McNamee (2011) stated that a positive approach to learning is a major contributor to the performance of the students, but their effectiveness is not the same in all activities. In addition, the effectiveness of the approach depends on the characteristics of the activity itself in which the child is involved. Various activities can be used by teachers in applying cognition in communications component. Aliza and Zamri (2015) stated that the play in curriculum is needed in teaching and learning in preschool, and it is recognized by preschool teachers. Preschool teachers recognize the importance and effectiveness of the play approach, but they do not practice it in teaching, and provide reason that they have no guidance on how to implement learning activities through play in teaching language and literacy in the classroom. Puteh and Ali (2012) also stressed the play approach in teaching language in preschool because it affects the development of cognitive, social, emotional and physical of a child. During play, students interact with their peers and adults through questioning, and through play students learn to communicate, interact and adapt to the environment.

In fact, previous studies showed that it is difficult for pre-school teachers to change the pattern of teaching, despite the effective use of play in teaching activities (Aliza and Zamri, 2015; Puteh and Ali, 2012; Einarsdottir, 2014).

In addition, language development can be promoted through activities like drama, poetry, social play, watching video or listening to music (Nachiappan, 2015; Holmes et al., 2015; Holmes and Romeo, 2013; Meacham et al., 2013). Holmes and Romeo (2013) found that gender and administration of the preschool is a factor that influenced language abilities and students' social games.

According to Holmes and Romeo (2013), students who regularly perform activities such as participation in drama, performed well in vocabulary test. However, preschool teachers are seen still difficult to plan their teaching because they lack knowledge about teaching content, and are less experienced in implementing a variety of approaches in the classroom (Jamian et al., 2015; Ehrlin and Wallerstedt, 2014).

According to Jamian et al. (2015), practicum teachers still lack practical experience in a real situation, which makes them face some difficulties in implementing the planned activities. While the findings showed that teachers are too comfortable with their teaching methods, despite the lack of knowledge about teaching content itself (Ehrlin and Wallerstedt, 2014). Therefore, this study is aimed to look at the preparatory teaching through the Daily Teaching Plan and the extent to which teachers apply cognition through the communication component in their preschool teaching.

\section{Research objectives}

i) To identify the teachers' shortcomings in the DTP preparation in teaching and learning of communication component in preschool.

ii) To identify the effectiveness of teaching aids in teaching and learning of communication component in preschool.

iii) To suggest ways to overcome the cognition application in teaching and learning of communication component in preschool.

\section{Methodology}

This qualitative research is based on Daily Teaching Plan practicum teachers of early childhood education. Therefore, the analysis of practicum teachers' Daily Teaching Plan cannot be generalized to all preschools. The researchers analyzed the Daily Teaching Plan document of a teacher, for a week, using the Hermeneutics method. Researchers analyzed explicitly and implicitly the data. According to Nachiappan (2015), the text is anything produced by humans in the form of written or oral used for transporting anything intended meaning, i.e. feelings, thoughts and people's behavior. The text contains implicit and explicit content to be interpreted.

This text reflects the characteristics of the cultural, social, feelings, thoughts of the present and the past, as well as the knowledge of the author, who was born in the form of the content (content) called "episodes". Attributes such as bias or prejudice or "bias" should be avoided during the process of interpreting texts. When researchers began to interpret the essay, the researcher will have "ontoenigma" which means ambiguity or lack of clarity about the content of the text. Next, when researchers started trying to find an explanation for understanding the meaning of the text, in the process those researchers began to discover the structure of the external and internal structure of the text.

The combination of these two structures can help researchers get away from the situation "ontoenigma" to "ontopretation" i.e. the process of deep understanding of the texts (Loganathan, 1992). This in-depth analysis of the elements in the unconscious that is implied in the texts will allow researchers to understand its meaning. This understanding is meta-texts that can give meaning to the original text. Meta-texts means of interpretation of the text of the findings (essay). An essay has what you want to understand the use of language by the individual style and also aspects of information 
processing experienced by individuals when writing essay. This essay text interpretation of results will be analyzed in the style that gives strength to the essay writing.

\section{Results}

Table 1: Application of cognition in teaching and learning through communication component

Daily Teaching Plan
(BM3.6) read phrases
(BM3.6.2) Read the phrase with the correct
pronunciation

Teachers questioning students on previous lessons

1. Teachers repeat what is taught. Teachers teach the way of reading the phrase.

2. Teachers distribute workbooks to students.

Teachers monitor the students to create a workbook

3. Teachers check the work of students. Teachers praise student's responses.

\section{(BM 3.5) Reading Words}

(BM 3.5.1)combine two syllables into words with guidance

Teachers questioned the last lesson. Associate teacher last lesson with new lessons.

1. Teacher distributes the exercise to the students. Teachers instruct the students to tell what is available in the classroom.

2 . The teacher directs students to spell all of the pictures contained in the exercises.

Teacher sets activities to guess the word.

Example: B _ a.

3. Teachers praise student's answers.

Teachers instruct students coloring the picture in the exercise.

(WM 3.5) Read the word. (WM 3.5.1) Divides two syllables to be words with guidance. 1.

Teacher asks students past lessons. 2. Repeat back what the Teacher taught. Teachers teach back way read the phrase. 3 . Teachers distribute workbooks to students. The teacher monitors the students make a workbook. 1. Teacher check students work. Teachers praise student's response.
The findings through interpretation of DTP documents, to see the application of cognition in the process of teaching and learning (TandL), showed that teachers often use question and answer as method of teaching about the previous lesson.

the

Teachers recalls on recent past teaching to identify if the students remember on what they have learnt. The students also describes about what they remember about what have they learned and tells it out in question and answer session with the teacher.

Teachers repeats on what they have taught before to help the students master it to read the phrasing correctly.

The students also listen to the instruction given by teachers well and repeat after the teacher reading the phrases.

Teachers gives out exercise to the students as a way to strength the student's understanding on what they have learnt and the students works on well on the exercises given.

The teachers checks on the exercises and see how the students have understood the teaching and on what to actually do in the exercise.

This will help to increase the student's understanding on learning about phrases. The students also will feel happy and motivated when teachers' compliment them for doing a good job.

With a sense for enthusiastic, teachers and students together start a session of teaching and learning. Teachers and students began to answer questions about the lessons that have been learned in the last teaching sessions. The students work more diligently to remembering the lessons back.

Students take exercises distributed by teachers and with a sense of eager to see the exercises provided by the teacher. Students observe attentively the given exercise and students try to mention the pictures on the exercise.

Students feel more confident to spell words on the exercises that have been distributed by the teacher. Students carefully spell the words one by one. Students get a positive strengthening of the teachers and they feel happy with the praise given by the teacher.

Students feel curious with the activities to be done by the teacher in the session today. Before continuing the lessons, the teacher told the students to remember past lessons back. Students with vigorous mention back fill the lessons they have learned properly. Students try to read back the phrase words about the content of the lesson today. Child mentions the word carefully and repeat the action until they can mention the phrase the word very well. With a sense of confident students to practice at training book distributed by the teacher. Students to practice in the book exercises with diligent and thorough. Students try to complete the exercise up to send it to the teacher. Students receive praise from teachers and feel fun to continue teaching after this session.

The teacher told the students to send training provided as the process of revision and teachers can find out errors made by students and students can improve the offence has been committed.

(WM 3.5) Read the word. (WM 3.5.1) Divides two syllables to be words with guidance. 1. Teacher asks back past lessons. Teacher associate past lessons with new lessons. 2 . The teacher distributes exercises to the teacher asks students what there is in the work sheet. 3 . Teachers refer to exercises and instruct student's reorganized alphabet to form words that correspond to the pictures. 4. The teacher directs students coloring exercises upon completion of arranging words. Teachers praise students coloring results

Through this method students will be able to process existing information and add new knowledge. They are even able to recall previous learning's if they have forgotten. But teachings are also seen as less attractive when teachers repeat the activities. Teachers also often use the same teaching materials, namely workbooks and exercises. This clearly shows that practicum teacher is not creative, less informative, and the teaching is more teachercentered. This is considered as weakness in 
application of cognition in teaching. In fact, this situation bores the students and it will be difficult for them to concentrate in class.

\section{Discussion}

Based on the findings of teachers' Daily Teaching Plan (DTP) interpretation in communication component, shows there are some shortcomings in the teachers' preparation. The factors identified were repetitive activities and teaching aids that are not attractive. The findings were also showed teacher often ask students about previous lesson, and as well as frequently use exercises and workbooks. This situation is repeated for the whole week of learning in the classroom.

DTP showed that practicum teachers also did not specify the approach and the types of teaching aids used. DTP prepared by the teachers is very important because it is a framework that guides teacher in doing the activities, from the initial process of teaching until the end of the teaching process. Therefore, this situation is very troubling because the effectiveness of the teaching is influenced by the teachers' teaching.

\section{Conclusion}

The practicum teachers have a few problems in the preparation of DTP. They frequently use Question and Answer technique and teaching materials such as workbooks and exercises. The effectiveness of teaching aids is not creative enough and less informative. The authorities should therefore find ways to overcome these problems.

\section{Acknowledgment}

Research Management and Innovation Centre (RMIC), Sultan Idris Education University.

\section{References}

Aliza A and Zamri M (2015). Analisis Keperluan Terhadap Pengguna Sasaran Modul Pendekatan Berasaskan Bermain Bagi Pengajaran Dan Pembelajaran Kemahiran Bahasa Kanak-Kanak Prasekolah. Jurnal Kurikulum and Pengajaran Asia Pasifik, 3(1): 1-8.

Alvestad T and Sheridan S (2015). Preschool teachers' perspectives on planning and documentation in preschool. Early Child Development and Care, 185(3): 377-392.

Chen JQ and McNamee GD (2011). Positive approaches to learning in the context of preschool classroom activities. Early Childhood Education Journal, 39(1): 71-78.

Ehrlin A and Wallerstedt C (2014). Preschool teachers' skills in teaching music: two steps forward one step back. Early Child Development and Care, 184(12): 1800-1811.

Einarsdottir J (2014). Play and literacy: A collaborative action research project in preschool. Scandinavian Journal of Educational Research, 58(1): 93-109.

Goldstein EB (2011). Cognitive psychology: connecting mind, research, and everyday experience. $3^{\text {rd }}$ Edition, Cengage Learning, Boston, USA.

Holmes RM and Romeo L (2013). Gender, play, language, and creativity in preschoolers. Early Child Development and Care, 183(11): 15311543.

Holmes RM, Romeo L, Ciraola S and Grushko M (2015). The relationship between creativity, social play, and children's language abilities. Early Child Development and Care, 185(7): 1180-1197.

Husin NFC, Isa ZM (2012). Effects of repeated reading towards understanding of kindergarten children. Jurnal Pendidikan Awal Kanak-Kanak, 1(1):1-16.

Jamian AR, Razali NN, and Othman S (2015). Capability for the Implementation of the trainee teacher training activities during the teaching practice to develop novice teachers. Jurnal Pendidikan Malaysia, 40(1): 75-81.

Loganathan K (1992). Hermeneutic Analysis of Discourse. International School of Dravidian Linguistics, India.

Meacham S, Vukelich C, Han M and Buell M (2013). Preschool teachers' language use during dramatic play. European Early Childhood Education Research Journal, 21(2): 250-267.

Nachiappan S (2015). Panduan Pendidikan Awal Kanak-Kanak: Teori, Model, Kaedah dan Aktiviti ke Arah Perkembangan Kognisi. Penerbit Universiti Pendidikan Sultan Idris, Tanjong Malim, Malaysia.

Noor Aini A (2014). Integrating Information and communication technologies as an aid in teaching language skills for children early age. Malay Language Education Journal (MyLEJ), 4(2): 36-43.

Puteh SN and Ali A (2012). Teachers' perceptions towards the use of play based curriculum in language and literacy development for preschoolers. Malay Language Education (MyLEJ), 2(1): 141-159.

Razak RA and Nordin SZS (2013). Projek Pembangunan Perisian Multimedia: Strategi Pengajaran Yang Membentuk Keperibadian Guru Pelatih. Jurnal Kurikulum and Pengajaran Asia Pasifik, 1(1): 42-52. 